\title{
Elucidating the Role of AII Amacrine Cells in Glutamatergic Retinal Waves
}

\author{
Alana Firl, ${ }^{1}$ ○liang-Bin Ke, ${ }^{2}$ Lei Zhang, ${ }^{2}{ }^{\oplus}$ Peter G. Fuerst ${ }^{3}$ Joshua H. Singer, ${ }^{2 \star}$ and Marla B. Feller ${ }^{4,5 *}$ \\ ${ }^{1}$ Vision Sciences Graduate Program, Department of Optometry and ${ }^{2}$ Department of Biology, University of Maryland College Park, College Park, Maryland \\ 20742, ${ }^{3}$ Department of Biological Sciences, University of Idaho, Moscow, Idaho 83844, and ${ }^{4}$ Department of Molecular and Cell Biology, and ${ }^{5} \mathrm{Helen}$ Wills \\ Neuroscience Institute, University of California, Berkeley, Berkeley, California 94720
}

\begin{abstract}
Spontaneous retinal activity mediated by glutamatergic neurotransmission-so-called "Stage 3" retinal waves— drives anti-correlated spiking in ON and OFF RGCs during the second week of postnatal development of the mouse. In the mature retina, the activity of a retinal interneuron called the AII amacrine cell is responsible for anti-correlated spiking in ON and OFF $\alpha$-RGCs. In mature AIIs, membrane hyperpolarization elicits bursting behavior. Here, we postulated that bursting in AIIs underlies the initiation of glutamatergic retinal waves. We tested this hypothesis by using two-photon calcium imaging of spontaneous activity in populations of retinal neurons and by making whole-cell recordings from individual AIIs and $\alpha$-RGCs in in vitro preparations of mouse retina. We found that AIIs participated in retinal waves, and that their activity was correlated with that of ON $\alpha$-RGCs and anti-correlated with that of OFF $\alpha$-RGCs. Though immature AIIs lacked the complement of membrane conductances necessary to generate bursting, pharmacological activation of the M-current, a conductance that modulates bursting in mature AIIs, blocked retinal wave generation. Interestingly, blockade of the pacemaker conductance $I_{\mathrm{h}}$, a conductance absent in AIIs but present in both ON and OFF cone bipolar cells, caused a dramatic loss of spatial coherence of spontaneous activity. We conclude that during glutamatergic waves, AIIs act to coordinate and propagate activity generated by $\mathrm{BCs}$ rather than to initiate spontaneous activity.
\end{abstract}

Key words: development; spontaneous activity; two-photon calcium imaging

\section{Introduction}

Spontaneous retinal activity, termed retinal waves, shapes visual system development (Huberman et al., 2008; Kirkby et al., 2013; Ackman and Crair, 2014). The circuitry underlying these waves changes as the retina matures. Initially, waves are generated and propagated by cholinergic interneurons called starburst amacrine cells; later, they depend upon glutamatergic transmission (Bansal et al., 2000; Zhou and Zhao, 2000; Wong and Wong, 2001; Maccione et al., 2014).

Starburst cells, which make reciprocal excitatory connections, depolarize spontaneously to initiate cholinergic waves (Zheng et al., 2006). Their activity then is propagated to other neurons, at least in part, by volume release of acetylcholine (Ford et al., 2012). Analogously, spontaneous depolarizations of glutamatergic in-

\footnotetext{
Received Aug. 7, 2014; revised 0ct. 28, 2014; accepted Nov. 23, 2014.

Author contributions: A.F., J.-B.K., L.Z., P.G.F., J.H.S., and M.B.F. designed research; A.F., J.-B.K., L.Z., P.G.F., and J.H.S. performed research; A.F. contributed unpublished reagents/analytic tools; A.F., J.-B.K., L.Z., P.G.F., J.H.S., and M.B.F. analyzed data; A.F., J.-B.K., P.G.F., J.H.S., and M.B.F. wrote the paper.

This work was supported by National Institutes of Health grants R01EY019498, R01EY013528, and P30EY003176 (M.B.F.); R01EY017836 (J.H.S.); and NIBIB T32 EB005586-05 (A.J.F.). We thank P. Han, C. Gainer, and M. Tong for technical assistance; members of the Feller lab for commenting on this manuscript; and James McFarland for a helpful discussion.

*J.H.S. and M.B.F. contributed equally to this work.

The authors declare no competing financial interests.

Correspondence should be addressed to Marla B. Feller, 142 Life Sciences Additions MSC 3200, University of California at Berkeley, Berkeley, CA 94720-3200. E-mail: mfeller@berkeley.edu.

DOI:10.1523/JNEUROSCI.3291-14.2015

Copyright $\odot 2015$ the authors $\quad 0270-6474 / 15 / 351675-12 \$ 15.00 / 0$
}

terneurons, primarily cone bipolar (CB) cells, should initiate glutamatergic waves that are propagated by volume release of glutamate (Firl et al., 2013).

The generation of glutamatergic waves, however, is only partially understood. Although CBs are depolarized by waves (Akrouh and Kerschensteiner, 2013; Firl et al., 2013), it is unknown if they initiate waves. Moreover, the mechanism(s) responsible for propagating these waves is yet to be fully elucidated. The two mechanisms that have been proposed are glutamate spillover (Blankenship et al., 2009; Firl et al., 2013) and gap-junction coupling (Akrouh and Kerschensteiner, 2013). Interestingly, a recent study demonstrated that pharmacological blockade of either ionotropic glutamate receptors or gap junctions was sufficient to prevent glutamatergic waves (Akrouh and Kerschensteiner, 2013), implicating both mechanisms in wave generation.

Synaptic inhibition also has been shown to shape glutamatergic waves (Sernagor et al., 2003; Maccione et al., 2014) by limiting the number of neurons activated (Firl et al., 2013) and by affecting wave timing. ON RGCs depolarize $\sim 1$ s before OFF RGCs, and this offset is eliminated when synaptic inhibition is blocked (Kerschensteiner and Wong, 2008). This anti-correlation of activity in ON and OFF RGCs caused by synaptic_-particularly glycinergic - inhibition suggests that AII amacrine cells play a critical role in the underlying circuitry (Kerschensteiner and Wong, 2008; Akrouh and Kerschensteiner, 2013).

AIIs are glycinergic interneurons in the INL. They receive excitatory input from rod bipolar cells, make inhibitory synapses 
onto some OFF ganglion cells (GCs) and OFF CBs, and are coupled by gap junctions to ON CBs and to each other (Famiglietti and Kolb, 1975; Demb and Singer, 2012). Initially thought to participate only in rod-mediated vision (Kolb and Nelson, 1983; Strettoi et al., 1992), they are now known to mediate "crossover" inhibition between $\mathrm{ON}$ and OFF pathways during conemediated vision: depolarization of ON CBs depolarizes AIIs and elicits inhibition of OFF RGCs (Manookin et al., 2008; Münch et al., 2009; van Wyk et al., 2009; Ke et al., 2014). This crossover inhibition generates anti-correlated spiking in ON and OFF $\alpha$-GCs that receive significant input from AIIs during both rodand cone-mediated vision (Margolis and Detwiler, 2007; Murphy and Rieke, 2008; van Wyk et al., 2009).

Since membrane hyperpolarization elicits bursting behavior in mature AIIs (Cembrowski et al., 2012) and since bursting in AIIs underlies rhythmic spiking anti-correlated in ON and OFF $\alpha$-GCs of the degenerating retina (Choi et al., 2014; Margolis et al., 2014), we hypothesized that glutamatergic waves are initiated by AIIs. To test this hypothesis, we used two-photon calcium imaging and targeted whole-cell recordings to determine how circuits in the inner retina-in particular, the network of coupled AIIs and $\mathrm{ON} \mathrm{CBs}$ - generate and propagate glutamatergic retinal waves.

\section{Materials and Methods}

Mice. Retinas were isolated from C57BL/6 wild-type (Harlan Laboratories), Fbxo32-eGFP, and Cdh1-eGFP mice of either sex and aged P9P12. Fbxo32-eGFP and Cdh1-eGFP mice express eGFP in AIIs (Gong et al., 2003; Siegert et al., 2009; Cembrowski et al., 2012; Kay et al., 2012). They were obtained from the Mutant Mouse Regional Resource Center [Stock (Tg:Fbxo32-EGFP)IM138Gsat/Mmucd, Stock \#030719-UCD and STOCK Tg(Cdh1-EGFP)AR201Gsat/Mmucd, Stock \#011775$\mathrm{UCD}$ ] and bred into the $\mathrm{C} 57 \mathrm{BL} / 6$ background. All procedures involving animals were approved by the Institutional Animal Care and Use Committees of the University of California (Berkeley, CA) and of the University of Maryland (College Park, MD) and conformed to the guidelines of the National Institutes of Health Guide for the Care and Use of Laboratory Animals, the Public Health Service Policy, and the Society for Neuroscience Policy on the Use of Animals in Neuroscience Research.

Retinal preparation. P9-P12 C57BL/6, Fbxo32-eGFP, and Cdh1-eGFP mice of either sex were deeply anesthetized with isoflurane and decapitated. Eyes were removed, and retinas were isolated in ACSF bubbled with carbogen $\left(95 \% \mathrm{O}_{2} / 5 \% \mathrm{CO}_{2}\right)$ containing the following (in $\mathrm{mM}$ ): $119.0 \mathrm{NaCl}, 26.2 \mathrm{NaHCO}_{3}, 11$ glucose, $2.5 \mathrm{KCl}, 1.0 \mathrm{~K}_{2} \mathrm{HPO}_{4}, 2.5 \mathrm{CaCl}_{2}$, and $1.3 \mathrm{MgCl}_{2}$. Retinal whole-mount preparations were prepared for electrophysiological and fluorescence-imaging recordings of retinal waves by mounting retinas' GC layer up on Anodisc filter paper (Whatman). Retinal slices (300-400 $\mu \mathrm{m}$ thick) were prepared by embedding retinas in 3\% agarose (Sigma type VIIA) in ACSF with HEPES substituted for $\mathrm{NaHCO}_{3}$ before cutting on a vibrating microtome (Leica). Retinal whole mounts and slices were stored in carbogen-bubbled ACSF at room temperature. During experiments, retinal preparations were superfused continuously with carbogen-bubbled ACSF heated to nearphysiological temperature $\left(30-34^{\circ} \mathrm{C}\right)$ at a rate of $1-2 \mathrm{ml} / \mathrm{min}$.

Immunohistochemistry. Retinas from Fbxo32-eGFP mice were fixed in $4 \%$ paraformaldehyde for $1 \mathrm{~h}$, rinsed in PBS, sunk in 30\% sucrose, and then finally equilibrated in a 50:50 mix of 30\% sucrose and OCT freezing media. Retinas were then frozen in OCT in a liquid nitrogen bath. Sections $(10 \mu \mathrm{m})$ were cut at on a cryostat. Sections were incubated in blocking solution (7.5\% normal donkey serum, $1 \times$ PBS, pH7.4, $0.1 \%$ Triton X-100) for $30 \mathrm{~min}$. Primary and secondary antibodies were diluted in this blocking solution. Primary antibodies were used at a concentration of 1:500 (DAB1; generous gift from Brian Howell) or 1:1000 (mouse anti-GFP; NeuroMab). Sections were incubated in primary antibody overnight at $4^{\circ} \mathrm{C}$. Sections were washed three times in PBS for $10 \mathrm{~min}$ each wash and then incubated in secondary antibodies (goat anti-mouse IgG2A, Invitrogen; donkey anti-rabbit cy3, Jackson ImmunoResearch) at dilutions of 1:1000. The nuclear dye Draq5 (Cell Signaling Technology) was incorporated with the secondary antibodies at a dilution of 1:2000. Sections were incubated in secondary antibodies for $2 \mathrm{~h}$ at room temperature. Sections were then washed three times in PBS for 10 min each wash and mounted in $80 \%$ glycerol. Whole retinas were stained in a similar fashion to sections except that the blocking solution contained $0.4 \%$ Triton X-100, the primary incubation was performed for $5 \mathrm{~d}$, the secondary incubation was performed for $2 \mathrm{~d}$ at $4^{\circ} \mathrm{C}$, and the washes were extended to $2 \mathrm{~h}$ each. Three retinas were imaged at either P8 or P11-P12 and consistent staining was observed between and within retinas. Tissue was imaged using an Olympus DSU spinning disk microscope. Any changes to the images, for example to brightness, were done across the image in accordance with journal policies.

To quantify the colocalization of GFP and DAB1, four fields intermediate between the optic disk and retina periphery were imaged in P8 and P12 retinas $(N=6$, three retinas for each age). The total number of $\mathrm{DAB} 1+\mathrm{GFP}+$ and DAB + GFP - AIIs in each field was counted to generate measurements of cell density (cells $/ \mathrm{mm}^{2} \pm$ deviation). From these counts, we generated an estimate of the percentage of AIIs that did not express GFP (DAB + GFP-/DAB + total).

Two-photon calcium imaging. Retinas were loaded with Oregon green 488 BAPTA-1 AM (OGB) using the multicell bolus loading technique (Stosiek et al., 2003; Blankenship et al., 2009). For identifying AIIs in Fbxo32-eGFP mice, retinas were imaged with the laser tuned to $920 \mathrm{~nm}$ to preferentially excite GFP before bolus loading. Two-photon calcium imaging of neurons in the INL and GCL was performed using a custommodified two-photon microscope (FluoView 300; Olympus America). $X Y Z$ scans were used to localize neurons in the GCL and INL. Time series images were acquired at $1 \mathrm{~Hz}$ using a $60 \times$ objective (Olympus LUMPlanFl/IR $\times 60 / 0.90 \mathrm{~W}$ ) with the excitation laser tuned to $790 \mathrm{~nm}$. Images were corrected for motion artifacts using the TurboReg ImageJ plugin. The $10 \times 10$ pixel $(12 \times 12 \mu \mathrm{m})$ regions of interest were selected manually within all cells in the field of view. Fluorescent signals were averaged within these regions over time. Cell events were identified when change in fluorescence exceeded $15 \%$ of the cell's baseline fluorescence within $1 \mathrm{~s}$. Cells were categorized as participating in a retinal wave if a cell's events were correlated with those of neighboring cells.

Electrophysiology. Both retinal slices and whole mounts were placed in a recording chamber mounted below an upright video microscope so that cells of interest could be visualized and targeted for whole-cell recordings with pipettes containing the following (in $\mathrm{mm}$ ): 110 K-gluconate, $5 \mathrm{NaCl}$, 10 HEPES, 1 BAPTA, 8 Tris-phosphocreatine, 4 MgATP, $0.4 \mathrm{NaGTP}$, and 0.05 Alexa 488, 594, or 647 hydrazide to permit visualization of the cells by epifluorescence or laser-scanning (confocal or two-photon; Thorlabs) imaging after recording ( $\mathrm{pH}$ adjusted to 7.4 by $\mathrm{KOH}$ and osmolarity to $\sim 280 \mathrm{mOsm}$ with sucrose). Drugs (from Tocris Bioscience) were added to the bath solution as follows: during recordings from retinal slices, synaptic transmission was blocked with DNQX (25 $\mu \mathrm{M}), \mathrm{CPP}(5 \mu \mathrm{M})$, strychnine $(1 \mu \mathrm{M})$, picrotoxin $(50 \mu \mathrm{M})$, and TPMPA $(50 \mu \mathrm{M})$, which block AMPA/KARs, NMDARs, GlyRs, GABA $\mathrm{A}$ Rs, and $\mathrm{GABA}_{\mathrm{C}}$ Rs, respectively; $\mathrm{M}$-type $\mathrm{K}$ conductances were blocked with linopirdine (LP; $50 \mu \mathrm{M})$ and activated with flupirtine $(30 \mu \mathrm{M})$; and $I_{\mathrm{h}}$ was blocked with ZD7288 (30 $\mu \mathrm{M})$.

For recordings from RGCs, $\alpha$-cells were targeted based on soma size (diameter $18-25 \mu \mathrm{m}$ ). AIIs in retinal whole-mount preparations prepared from Cdh1-eGFP mice were targeted for recording by visualizing eGFP fluorescence. In retinal slice preparations, AIIs were identified by soma size and shape and position at the border of the INL and inner plexiform layer (IPL). Access resistances were $<25 \mathrm{M} \Omega$ and were not compensated. Recordings were made using a single Multiclamp 700B amplifier. Recorded voltages were low-pass filtered at $1-2 \mathrm{kHz}$ and digitized at $1-10 \mathrm{kHz}$ by an ITC-18 A/D board (InstruTech) controlled by software written in Igor Pro (WaveMetrics). Analyses were performed in Igor Pro.

Waves were detected as follows: first, data were low-pass filtered digitally (Bessel filter; $10 \mathrm{~Hz}$ cutoff) and smoothed (50 point sliding average) to remove spikes and other fast membrane voltage fluctuations; second, waves were detected as voltage excursions above a threshold (usually +2 
$\mathrm{mV}$ from baseline) lasting $>100 \mathrm{~ms}$. All data processed by this algorithm were inspected by eye to ensure their reliability. Differences between samples were assessed for significance using a two-tailed Wilcoxon signed-rank test (called Wilcoxon test, below) for paired samples. Significance was taken as $p<0.05$.

\section{Results}

\section{AIIs participate in glutamatergic waves}

In mature Fbxo32-eGFP mice, AIIs, which are uniformly distributed in the inner part of the inner nuclear layer, as well as other neuronal types deeper in the inner nuclear layer express GFP (Siegert et al., 2009; Cembrowski et al., 2012). To confirm that developing AIIs of Fbxo32-eGFP mice expressed GFP, we assessed colocalization of anti-GFP and anti-Dab1 immunofluorescence (Fig. 1A); Dab1 (disabled 1) is a protein that, in the retina, is expressed specifically by AIIs (Rice and Curran, 2000; Lee et al., 2003, 2004; Fuerst et al., 2009). We found that nearly all AIIs were GFP $+(\mathrm{P} 8: 88 \pm 4 \%, n=3$ retinas; Fig. $1 B$; P12: $90 \pm$ $1 \%, n=3$ retinas; data not shown).

Given the AIIs' abilities to synchronize activity in electrically coupled ON CBs and to generate crossover inhibition that anticorrelates activity in ON and OFF RGCs (Demb and Singer, 2012), it would seem that these cells are well positioned to play a significant role in the generation and/or propagation of glutamatergic waves (Akrouh and Kerschensteiner, 2013). As a starting point for our study, we schematized a hypothetical circuit that generates and propagates glutamatergic retinal waves (Fig. 1B). Since previous calcium-imaging experiments indicate that rod bipolar cell somas do not depolarize during waves (Firl et al., 2013), we assume that depolarization of AIIs is either intrinsic or mediated by glutamate spillover and/or electrical synapses with ON CBs.

We verified that AII cells were depolarized by retinal waves by two-photon calcium imaging of retinas from Fbxo32-eGFP mice in which AIIs express eGFP. Our two-photon calcium imaging offered a limited field of view relative to that observed in previous epifluorescence imaging-based studies (Blankenship et al., 2009; Ford et al., 2012). The technique, however, allowed us to image the INL and GCL independently (Briggman and Euler, 2011; Firl et al., 2013) and to record calcium transients in different neuronal populations by varying the depth of the imaging plane without contamination from out-of-focus fluorescence.

We found the same pattern of expression of GFP + cells in the live retina as determined with two-photon imaging (Fig. 1C). The $\mathrm{GFP}+$ cells closest to the IPL displayed wave-related calcium transients in conjunction with other INL neurons (Fig. 1C-E). We found that $\sim 50 \%$ of these AIIs participated in retinal waves (Fig. $1 F$ ) and exhibited calcium transients at the same frequency as other neurons in the INL and GCL (Fig. 1G). Thus AIIs appeared to be depolarized by retinal waves. It is important to note that the ability of two-photon calcium imaging to detect depolarization of a cell is limited by the signal-to-noise ratio of the transients, which in turn vary with the magnitude of the depolarization. Immature AIIs depolarize by only a few millivolts during waves (see below) and do not fire action potentials, limiting the activation of voltage-gated Ca channels subsequent to $\mathrm{Ca}^{2+}$ influx. Hence, calcium imaging is likely to underestimate the participation of AIIs in waves.

To better ascertain the participation of AIIs in retinal waves, we made simultaneous, whole-cell current-clamp recordings from AIIs and RGCs (Fig. 2). In all dual recordings ( $n=8$ AII-ON RGC pairs, $n=11$ AII-OFF RGCs) depolarizations in AIIs were largely correlated with depolarizations in RGCs (Fig.
$2 A$ ), and waves in both cell types were blocked by iGluR antagonists $(n=3$; Fig. 2A). On average, RGCs depolarized every $27.6 \pm$ $4.2 \mathrm{~s}$ and AIIs every $26.6 \pm 2.9 \mathrm{~s}$ (mean \pm SEM; difference is not significant; $p=0.74$; Fig. $2 B$ ). Waves recorded in AIIs varied widely in amplitude (average $=6.3 \pm 3.4 \mathrm{mV}$, mean $\pm \mathrm{SD}$; range $=2.1-15.0 \mathrm{mV} ; n=22$ ). The smaller depolarizations (average amplitude in 12/22 AIIs $<6 \mathrm{mV}$ ) observed likely account for the $50 \%$ participation rate established with calcium imaging; i.e., a subset of AIIs does not depolarize sufficiently to generate $\left[\mathrm{Ca}^{2+}\right]$ sufficient to visualize.

To examine the temporal relationship between waves in AIIs in RGCs, we measured the times between each depolarization in the AII and the closest (temporally) depolarization in the RGC for every paired AII-RGC recording and found that depolarizations of the two cells in a pair were well coordinated: $61 \%$ of depolarizations in an AII was accompanied by depolarizations in an ON RGC, and $48 \%$ of depolarizations in an AII was accompanied by depolarizations in an OFF RGC (148/238 waves for $n=8$ AII-ON RGC pairs and 132/275 waves for $n=12$ AII-OFF RGC pairs). The absence of completely coordinated activity in the two cells likely reflects the fact that waves have a finite propagation distance and propagate in multiple directions across the retina; the cells we recorded from were displaced laterally up to $\sim 100$ $\mu \mathrm{m}$ from each other.

Measurements of AII-RGC timing differences pooled from AII-ON RGC pairs $(n=8)$ and from AII-OFF RGC pairs $(n=$ 12) revealed that depolarizations in AIIs were followed closely by depolarizations in ON RGCs (median delay = $295 \mathrm{~ms}$ ), while depolarizations in OFF RGCs occurred with a more substantial delay (median delay $=855 \mathrm{~ms}$; Fig. $2 C$ ). These data support the conclusion that activity in AIIs is correlated with activity in the ON pathway (Akrouh and Kerschensteiner, 2013).

\section{AIIs in the developing retina do not burst but rather alter the timing of crossover inhibition}

Our observation that spontaneous depolarizations of AIIs are absent in the presence of iGluR antagonists suggests that the cells are not intrinsically oscillatory, as they are in the degenerated retina (Choi et al., 2014; Margolis et al., 2014). Rather, AIIs appeared to be driven by chemical and/or electrical synaptic inputs.

Given this observation, we wished to determine whether developing AIIs are capable of generating intrinsic bursts. Therefore, we made whole-cell current-clamp recordings from AIIs in a retinal slice preparation and examined their responses to injected current when chemical synaptic transmission was blocked (see Materials and Methods). Current steps (generally $\pm 30 \mathrm{pA}$; Fig. $3 A)$ or ramps $( \pm 50 \mathrm{pA}$ over $2 \mathrm{~s}$; Fig. $3 B)$ were injected into AIIs and voltage changes recorded.

We found that immature AIIs differed substantially from the mature ones described previously. Unlike AIIs in the mature retina (Boos et al., 1993; Tian et al., 2010; Cembrowski et al., 2012), immature AIIs did not exhibit $\mathrm{Na}$ channel-dependent spikes when depolarized above resting $\mathrm{V}_{\mathrm{M}}$, which averaged $-55.9 \pm 3.0$ $\mathrm{mV}$ ( $n=12$ cells); resting $\mathrm{V}_{\mathrm{M}}$ in these AIIs was $\sim 10 \mathrm{mV}$ hyperpolarized relative to that of mature AIIs (Fig. $3 B, C$; Cembrowski et al., 2012). Additionally, immature AIIs had high input resistances $\left[\mathrm{R}_{\mathrm{N}}=1.15 \pm 0.1 \mathrm{G} \Omega\right.$ as measured between -80 and -70 $\mathrm{mV}(n=12$ cells $)]$; this is approximately twice the $\mathrm{R}_{\mathrm{N}}$ measured from mature AIIs (Cembrowski et al., 2012).

Immature AIIs, however, appeared to exhibit M-type K-currents, just as mature AIIs do (Cembrowski et al., 2012). Depolarizing AIIs above $-40 \mathrm{mV}$ resulted in a significant reduction in $\mathrm{R}_{\mathrm{N}}$, to $0.80 \pm 0.1 \mathrm{G} \Omega(p=0.006 ; n=12$ cells $)$, indicative 
A
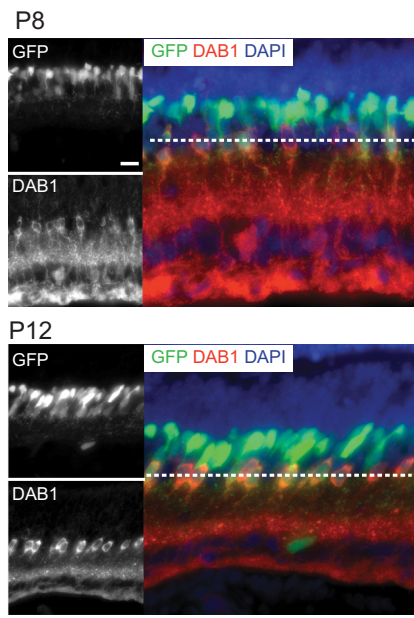
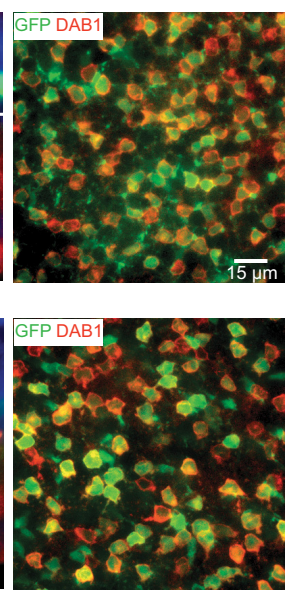

B

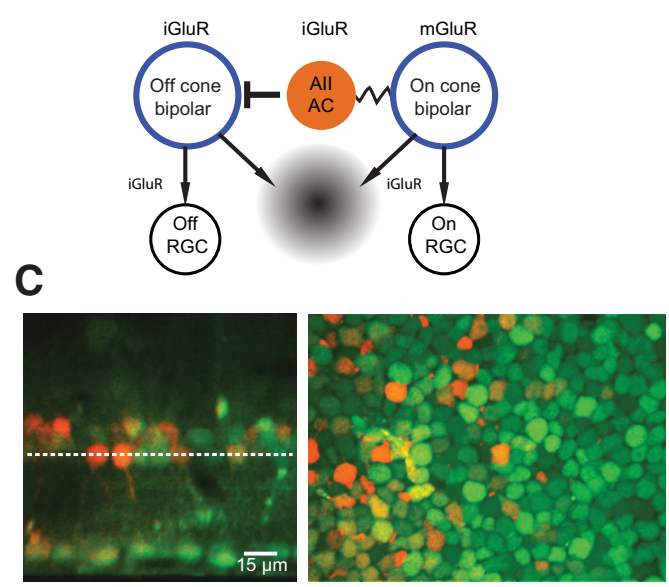

D

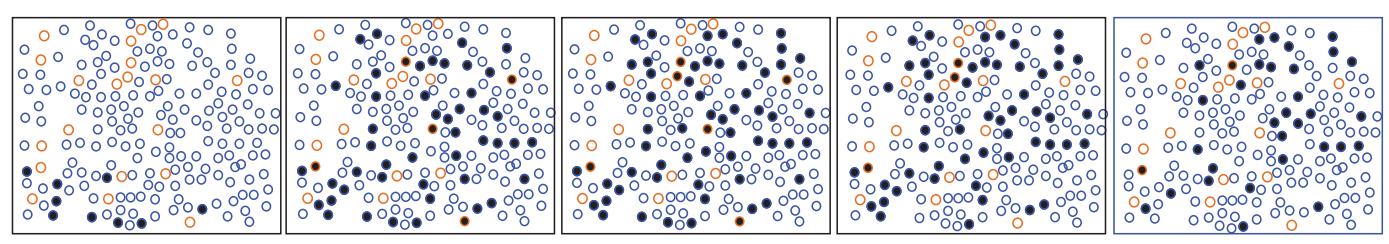

E
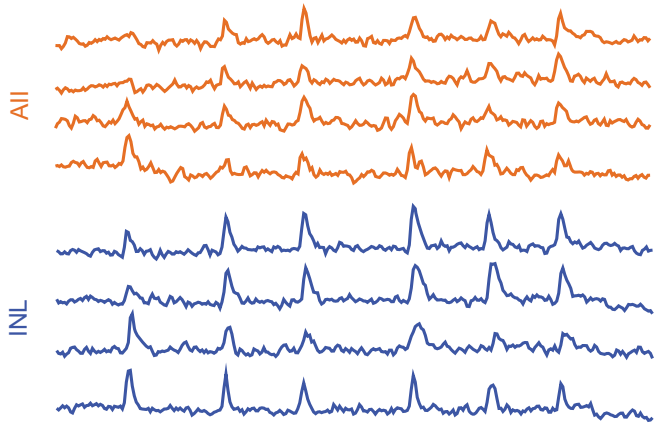

$20 \% \Delta \mathrm{F} / \mathrm{F}$

$30 \mathrm{sec}$

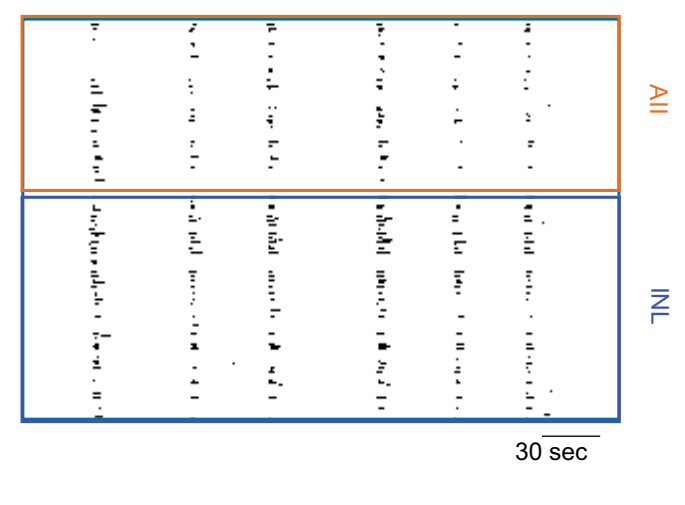

$\mathbf{F}$

Proportion of cells that participate in waves

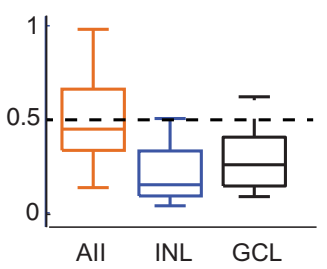

G

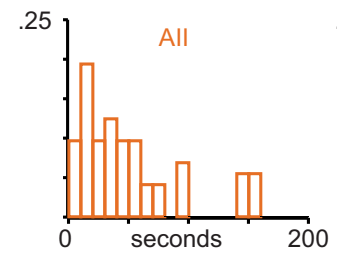

inter-wave interval

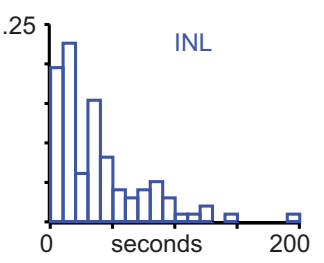

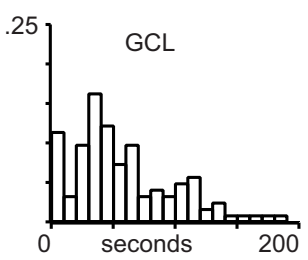

Figure 1. Alls are depolarized during waves. A, Fluorescence confocal images from sections (left) and whole-mount retina (right) from P8 (top) and P12 (bottom) Fbxo32-GFP mice stained with antibodies to GFP and disabled (Dab1), a marker for All amacrine cells. Dotted line depicts z-plane. Scale bar, $15 \mu \mathrm{m}$. B, Schematic of inner nuclear circuit for retinal waves. Wave starts when 0N-CBs depolarize, Alls are depolarized either via gap junction coupling or glutamate spillover (gray gradient). Alls inhibit OFF-CBs. Alls then release inhibition onto OFF-CBs, causing them to release glutamate and starting the wave OFF phase. C, INL loaded with OGB, GFP-expressing Alls overlaid in orange (right), and optical reconstruction of retinal cross section (left), GCL on bottom. Dotted line depicts z-plane. Scale bar, $15 \mu \mathrm{m}$. D, Example of wave propagation in the INL observed with two-photon calcium imaging at a frame rate of $1 \mathrm{~Hz}$. Orange circles are identified All amacrine cells, blue circles are unidentified cells in INL, and black indicates INL neurons with $\Delta F / F$ of $>15 \%$ for the first time in that frame. $E$, Left, Sample $\Delta F / F$ traces from representative cells, in Alls (top) and other unidentified INL neurons (bottom). Right, Raster plots of neuronal calcium transients of $>15 \% \Delta F / F$ for all All amacrine cells in the field of view (top), and other unidentified INL neurons (bottom). The total imaging duration was $8 \mathrm{~min} . \boldsymbol{F}$, Boxplot comparison of proportion of cells depolarized by waves in Alls, GCL cells, and unidentified INL neurons. Medians plotted with whiskers extending to the most extreme values that are still considered not to be outliers. $G$, Histogram of interwave intervals for calcium imaging from the both the GCL and the INL. In a subset of experiments, recordings were performed in Fbx032-eGFP mice in which Alls express eGFP and therefore interwave intervals for Alls were determined. 
A

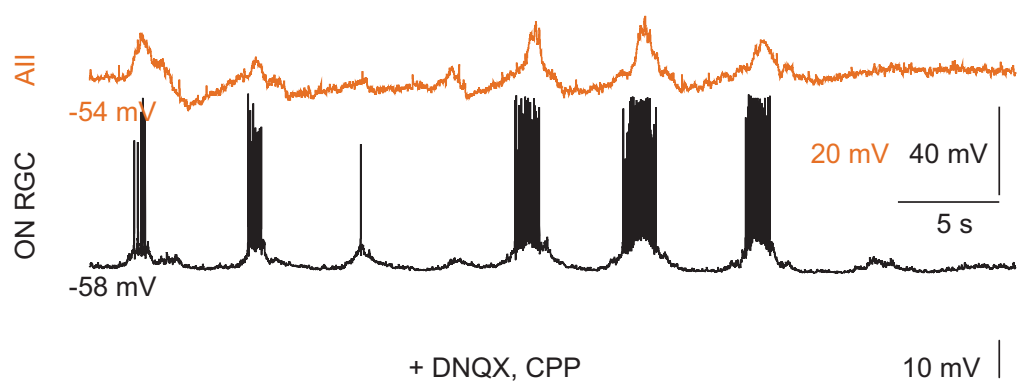

$-59 \mathrm{mV}$

$-55 \mathrm{mV}$

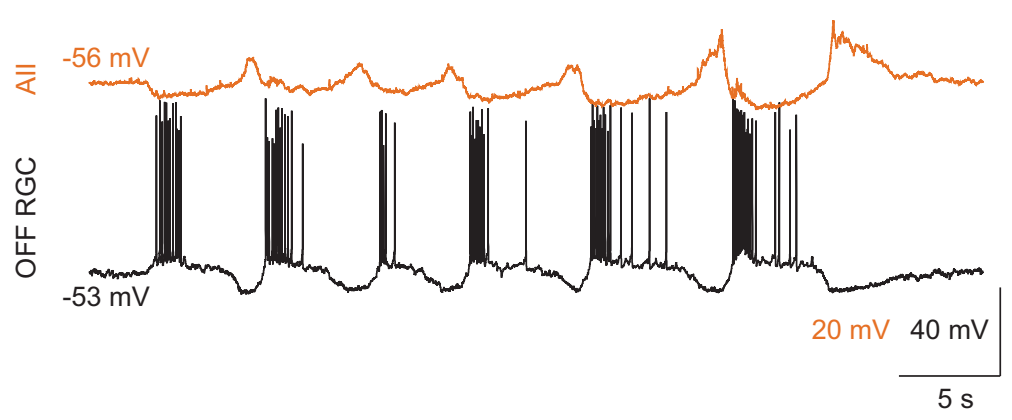

B
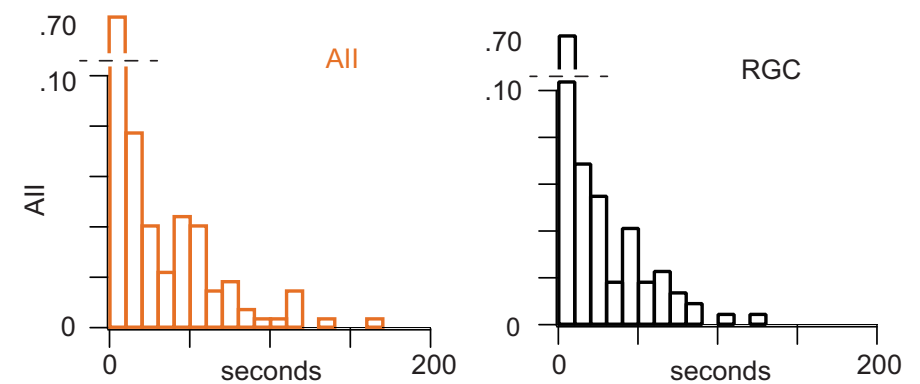

C

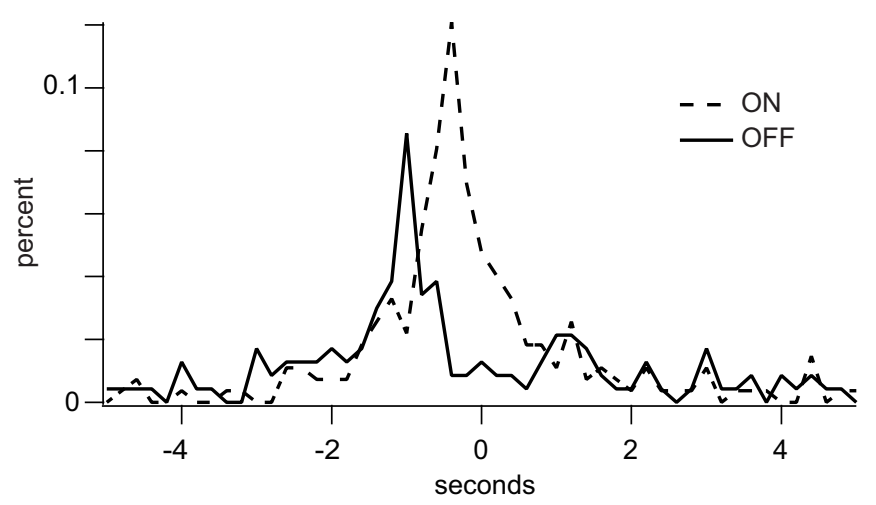

Figure 2. Alls are correlated with ON-RGCs and anti-correlated with OFF-RGCs during waves. $\boldsymbol{A}$, Top, Concurrent current-clamp recordings of spontaneous depolarizations in an All (gold) and an ON RGC (black). Note that spiking in the RGC is accompanied by depolarization of the All; the All appears to hyperpolarize during the interwave interval. Middle, CPP and DNQX, antagonists of ionotropic GluRs, block activity in both cells. Bottom, Concurrent current-clamp recordings from an All (gold) and an OFF RGC (black) illustrate spontaneous depolarizations in the two cell types. Note that the RGC stops spiking and hyperpolarizes when the All depolarizes; the All is hyperpolarized while the RGC spikes. $\boldsymbol{B}$, Summary data of interwave intervals for Alls and in RGCs. $\boldsymbol{C}$, Normalized histograms showing timing differences between waves in Alls and waves in RGCs. Differences were measured for each recorded All-RGC pair, and data from All-ON RGC pairs and All-0FF RGC pairs were pooled. Depolarizations in Alls preceded closely depolarizations in ON RGCs; depolarizations in Alls preceded depolarizations in OFF RGCs $>800 \mathrm{~ms}$. of the opening of a voltage-gated conductance at these potentials. Addition of the M-current antagonist LP $(50 \mu \mathrm{M})$ blocked this reduction in $R_{N}$ (in $L P, R_{N}$ measured at -80 to $-70 \mathrm{mV}=1.23 \pm 0.1 \mathrm{G} \Omega$, and $\mathrm{R}_{\mathrm{N}}$ measured at -40 to $-30 \mathrm{mV}=1.08 \pm$ $0.1 \mathrm{G} \Omega$; this difference is not significant; Fig. $3 B ; p=0.08 ; n=12$ cells) and depolarized the cells by $\sim 5 \mathrm{mV}$, to $\mathrm{V}_{\mathrm{M}}=50.0 \pm$ $3.1 \mathrm{mV}$ (Fig. 3B, $C ; p=0.0005 ; n=12$ ).

Blockade of the M-current also affected the structure and frequency of spontaneous depolarizations recorded in AIIs and RGCs (Fig. 3D). In the presence of LP, the distribution of interevent intervals was shifted toward smaller intervals for AIIs and for both ON and OFF RGCs (Fig. 3E; AII wave interval: control $15.86 \pm 26.40 \mathrm{~s}, n=271$ waves; LP $8.14 \pm$ 20.75 s, $n=144$ waves; $p=0.60$ Wilcoxon signed-rank test; ZD7288 5.17 $\pm 5.73, n=$ 436 waves; $p<0.001$ Wilcoxon signedrank test; RGC wave intervals: control $12.80 \pm 20.75$ s, $n=218$ waves; LP $3.62 \pm$ 3.33, $n=143$ waves; $p<0.001$ Wilcoxon signed-rank test; ZD7288 $4.40 \pm 6.15 \mathrm{~s}$, $n=389$ waves; $p<0.001$ Wilcoxon signed-rank test).

To monitor the effects of LP and an M-current activator, flupirtine (FL; 10 $\mu \mathrm{M})$ across a larger population of neurons in both the GCL and INL, we used twophoton calcium imaging. Application of LP produced more frequent transients in INL and GCL neurons (Fig. 4B,D; Wilcoxon signed-rank test $p=0.01$; wave interval: control $202.4 \pm 90.6$ s, $N=21$ waves, 5 retinas; LP $92.7 \pm 32.8 \mathrm{~s}, N=43$ waves). LP also induced longer calcium transients in the AIIs (Fig. 4B), consistent with previous reports of prolonged depolarization induced by LP in AIIs of normal and $r d 1$ retinas (Cembrowski et al., 2012; Choi et al., 2014). LP, however, did not affect the proportion of AIIs or GCL cells that participated in waves (Fig. $4 C$; control $0.84 \pm 0.010$, LP $0.92 \pm 0.071 ; n=4$ retinas; Student's $t$ test $p=0.19$ )

In contrast, FL blocked waves, abolishing calcium transients in AIIs and in other neurons in the INL and GCL (Fig. 4A). We also saw a blockade of spontaneous depolarization in whole-cell current-clamp recordings from AIIs and RGCs $(n=3$ paired recordings; data not shown). These data indicate that strong hyperpolarization of AIIs was sufficient to stop the generation of retinal waves.

We conclude that intrinsic membrane conductances of AIIs do not support intrinsic bursting; therefore it is unlikely that glutamatergic waves originate with spontaneous depo- 
A All

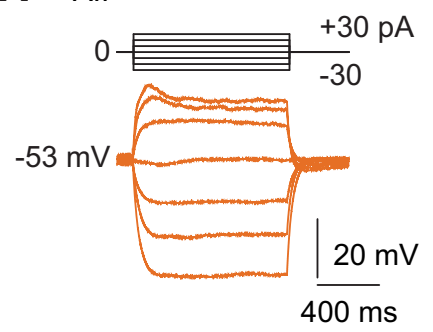

\section{B}

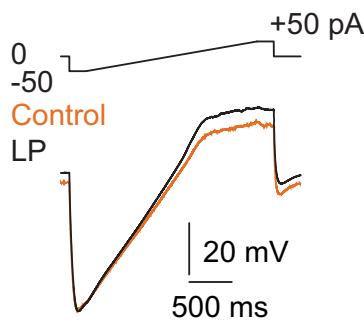

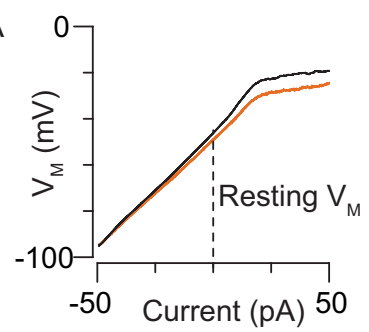

C

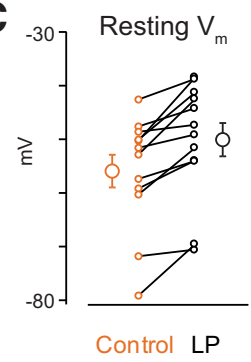

D
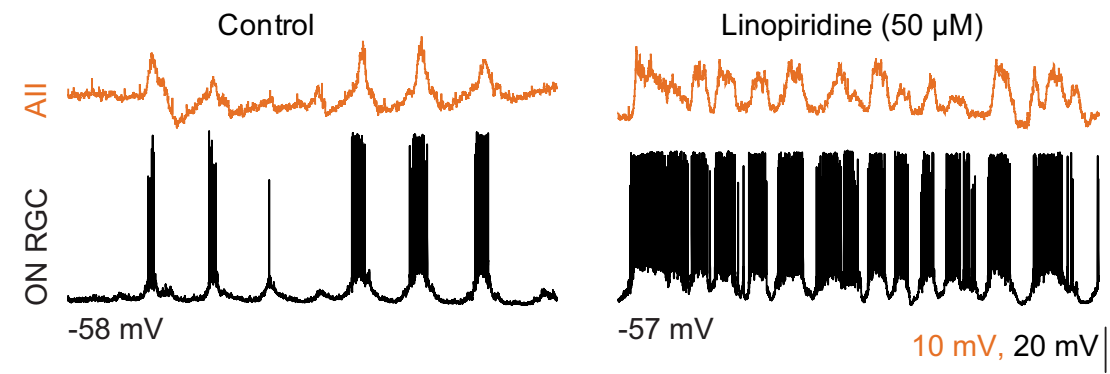

E

Inter-event Intervals - All Inter-event Intervals - RGCs

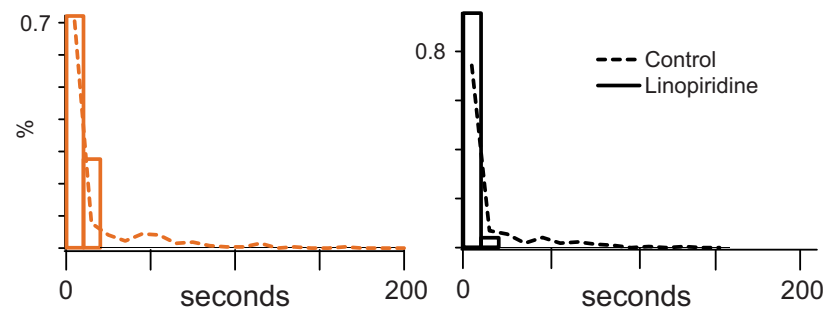

Figure 3. Blocking M-current alters the frequency of spontaneous depolarizations. $A$, Current-clamp recording of All responses to hyperpolarizing and depolarizing current injection. Note the lack of hyperpolarizing sag or of any spiking upon depolarization. $\boldsymbol{B}$, Current-clamp recordings from Alls show responses to injected current ramps in the absence and presence of the $M$-current antagonist linopirdine (LP). This protocol was used to measure the input resistance $\left(R_{N}\right)$ as a function of membrane potential. $C$, Summary data for effects of $L P$ on resting potential of Alls. $D$, Example recording of effects of $L P$ on spontaneous depolarization in both Alls and RGCS. Control trace same as that in Figure 2A.E, Summary data illustrate a reduction in average interwave interval. Dotted line represents distribution from Figure $2 B$.

larizations of AIIs. Therefore, we wished to determine whether immature CBs exhibited intrinsic properties consistent with spontaneous depolarization and/or bursting.

\section{CB cells possess $I_{h}$, the blockade of which significantly alters wave properties}

We recorded from $\mathrm{ON}$ and OFF CBs (identified by visualization of fluorescent tracer following recording; see Materials and Methods) in retinal slice preparations in the current-clamp configuration and examined cells' responses to injected currents (generally $\pm 30 \mathrm{pA}$; Fig. $5 A, B$ ). In $4 / 5 \mathrm{ON}$ cells and in $7 / 8 \mathrm{OFF}$ cells, we observed a significant depolarizing "sag" in response to hyperpolarizing current injection as well as a depolarizing potential following the termination of hyperpolarizing current injection; this sag and afterdepolarization are indicative of the activation of $I_{h}$, a hyperpolarization-activated depolarizing conductance (Lüthi and McCormick, 1998). In all cases, this sag and the following afterdepolarization were blocked by the $I_{\mathrm{h}}$ antagonist ZD7288 (Fig. 5A,B). $I_{\mathrm{h}}$ also has been observed in recordings from mature CBs (Ma and Pan, 2003); therefore it would seem that the intrinsic membrane properties of CBs, unlike those of AIIs, are established early in development.

Next, we examined the effects of ZD7288 on retinal waves. ZD7288 increased the frequencies of spontaneous depolarization in AIIs and RGCs, as assessed by whole-cell recordings (Fig. $5 C, D)$. Two-photon calcium imaging revealed a dramatic effect of ZD7288 on the spatial correlations of glutamatergic waves (Fig. 6A,B): GCL and INL neurons exhibited more frequent bursts (reported as median, lower quartile/upper quartile; control: 36, 20/82 s, $N=150$ wave intervals; ZD7288: 6, 3/12 s, $N=$ 62 wave intervals; Fig. $6 E$ ). The proportion of cells active during waves increased for cell types in both the INL and GCL, including AIIs (GCL: control $0.16 \pm 0.12$, ZD7288 $0.68 \pm 0.12$; INL: control $0.38 \pm 0.11$, ZD7288 0.57 \pm 0.065 ; AIIs: control $0.50 \pm 0.27$, ZD7288 $0.87 \pm 0.12$; Fig. $6 C$ ). The proportion of cells that never displayed significant calcium transients decreased, most notably for AIIs, for which it dropped to zero (GCL: control $0.69 \pm 0.24$, ZD7288 0.089 \pm 0.072; INL: control $0.37 \pm 0.21$, ZD7288 $0.059 \pm 0.049$; AIIs: control $0.36 \pm 0.27$, ZD7288 $0 \pm 0$; Fig. $6 D$ ). Hence, blockade of $I_{\mathrm{h}}$ significantly increased the participation of INL neurons in retinal waves.

\section{Absence of gap junctions does not limit AIIs' participation in waves}

AIIs are coupled electrically to other AIIs and to ON CBs by gap junctions comprising connexin $(\mathrm{Cx})$ proteins, of which there are many subtypes (Demb and Singer, 2012; Völgyi et al., 2013). $\mathrm{AII} \rightarrow$ AII gap junctions are Cx36 homotypic (Deans et al., 2002), 
A

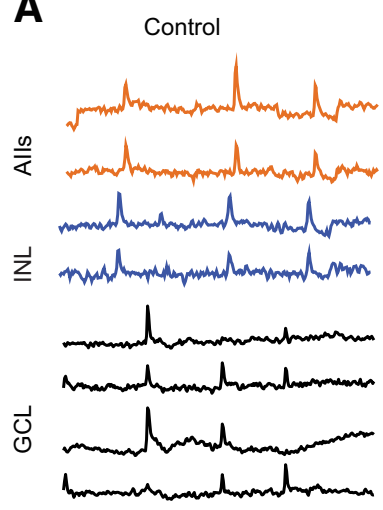

Flupirtine $(30 \mu \mathrm{M})$

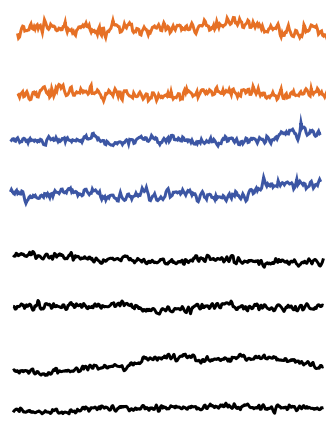

$20 \% \Delta \mathrm{F} / \mathrm{F}$
B

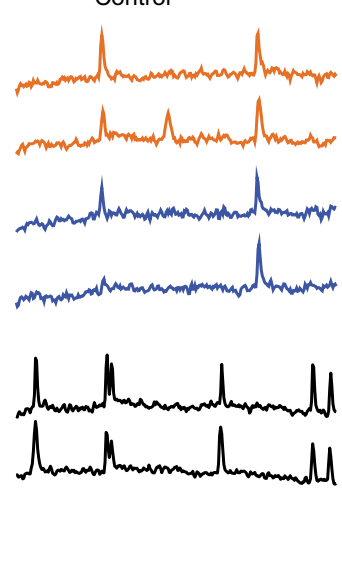

Linopirdine $(30 \mu \mathrm{M})$
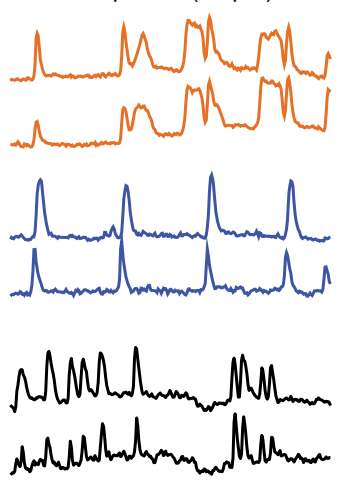

$25 \% \frac{\Delta \mathrm{F} / \mathrm{F}}{1 \mathrm{~min}}$
C

Proportion of cells that participate in waves
D
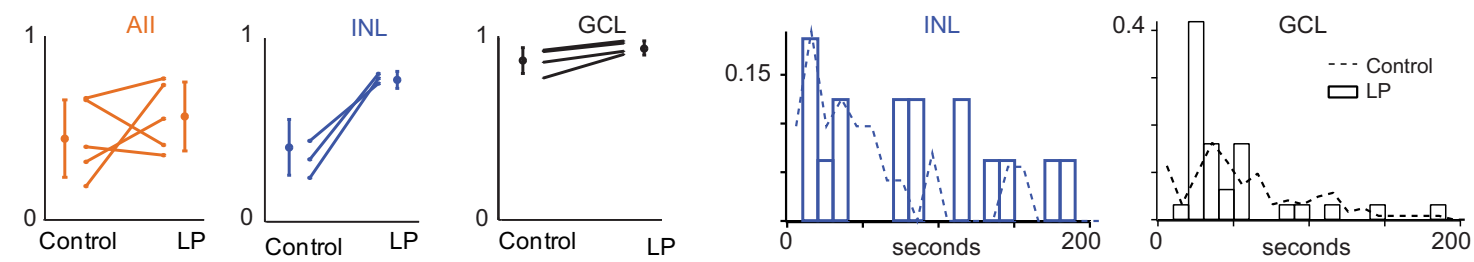

Figure 4. Altering the M-current alters the properties of retinal waves. $A$, Sample $\Delta F / F$ traces from representative cells, in control ACSF (left) and after flupirtine (right), and in Alls (top), other unidentified INL neurons (middle), and GCL neurons (bottom). $\boldsymbol{B}$, Sample $\Delta F / F$ traces from representative cells, in control ACSF (left) and after LP (right) in Alls (top), other unidentified INL neurons (middle), and GCL neurons (bottom). C, Summary of effects of $L P$ on the average proportion of cells that participated per wave. Lines connect values of average cell participation per wave for one retina in control versus LP among Alls (left), INL neurons (middle), and GCL (right). Open circles are group means and SD. D, Summary of effects of LP on the distribution of interwave interval. Dotted lines represent distributions from Figure $1 F$.

and $\mathrm{AII} \rightarrow \mathrm{ON}$ CB gap junctions are $\mathrm{Cx} 36 / 45$ heterotypic (Güldenagel et al., 2000; Feigenspan et al., 2001, 2004; Lin et al., 2005; Maxeiner et al., 2005). To determine how electrical coupling within the AII network shapes glutamatergic waves, we used twophoton calcium imaging to examine the spatiotemporal pattern of activity in retinas from Cx36 ko and Cx36/45 dko mice.

Previously we used a multi-electrode array (MEA) to characterize the spontaneous firing patterns of retinas from Cx36 ko and Cx36/45 dko mice (Hansen et al., 2005; Torborg et al., 2005; Blankenship et al., 2011). In these studies, we recorded retinal waves from both Cx36 ko and Cx36/45 dko retinas; RGCs from these retinas also exhibited many uncorrelated action potentials in between waves. Here we assessed the spontaneous calcium transients of the neurons in the INL in these retinas. Similar to observations of firing patterns of RGCs, waves were detected in the INL, and the interwave intervals did not vary significantly across genotypes (data not shown; Kruskal-Wallis test; INL: WT, $n=18$ waves; Cx36 ko, $n=97$ waves; Cx36/45 dko, $n=19$ waves; GCL: WT, $n=16$ waves; Cx36 ko, $n=49$ waves; Cx36/45 dko, $n=17$ waves). Cx36 ko and Cx36/45 dko retinas, however, exhibited higher frequencies of uncorrelated interwave calcium transients in the INL and GCL layers (Fig. 7A), consistent with previous MEA recordings (Blankenship et al., 2011). In the case of Cx36 ko, AIIs still participated in waves (Fig. $7 B$ ). Compared with WT, the $\mathrm{Cx} 36$ ko and $\mathrm{Cx} 36 / \mathrm{Cx} 45$ dko mice showed a higher proportion of cells in the GCL displaying calcium transients during waves(Figure 7C,D; Kruskal-Wallis test, $p=0.035$; INL: WT, $n=9$ retinas; $\mathrm{Cx} 36 \mathrm{ko}, n=21$ retinas; $\mathrm{Cx} 36 / 45 \mathrm{dko}, n=5$ retinas; GCL: WT, $n=4$ retinas; Cx36 ko, $n=6$ retinas; Cx36/45 dko, $n=$ 4 retinas; differences found between $\mathrm{Cx} 36$ ko and WT in GCL;
Tukey-Kramer post hoc tests). Thus, gap junctions play a role in controlling cell participation during waves.

\section{Discussion}

We have clarified the role that AIIs play in the generation and propagation of glutamateric retinal waves. Using both twophoton calcium imaging (Fig. 1) and targeted whole-cell recordings (Fig. 2), we demonstrated that AIIs participate in retinal waves and that they are depolarized concurrent with neighboring RGCs. AIIs' intrinsic membrane properties, however, do not support a role in wave initiation for these cells, and we conclude that AIIs do not serve as the pacemakers for glutamatergic retinal waves. Rather AIIs appear to provide inhibition necessary to anticorrelate activity in ON and OFF ganglion cells (Akrouh and Kerschensteiner, 2013), and M-type $\mathrm{K}^{+}$conductances in AIIs modulate signal propagation through the electrically coupled network of AIIs and ON CBs (Figs. 3, 4). We hypothesize that wave initiation depends upon oscillations in the membrane potentials of $\mathrm{CBs}$, and that the hyperpolarization-activated, depolarizing $I_{\mathrm{h}}$ permits these oscillations to be synchronized by synaptic inhibition (Figs. 5, 6). This conclusion is supported by previous observations in the adult retina that CBs possess both $I_{\mathrm{h}}$ and calcium channel-dependent oscillatory activity (Protti et al., 2000; Ma and Pan, 2003; Ma et al., 2005; Toychiev et al., 2013). Of course, the channels underlying $I_{\mathrm{h}}$ and M-type $I_{K}$ are likely to be found in interneurons other than CBs and AIIs, respectively (Cangiano et al., 2007); our data do not preclude contributions from such neurons to wave generation and/or propagation. Indeed, we observe many other neurons within the inner nuclear layer that are depolar- 
A ON CB
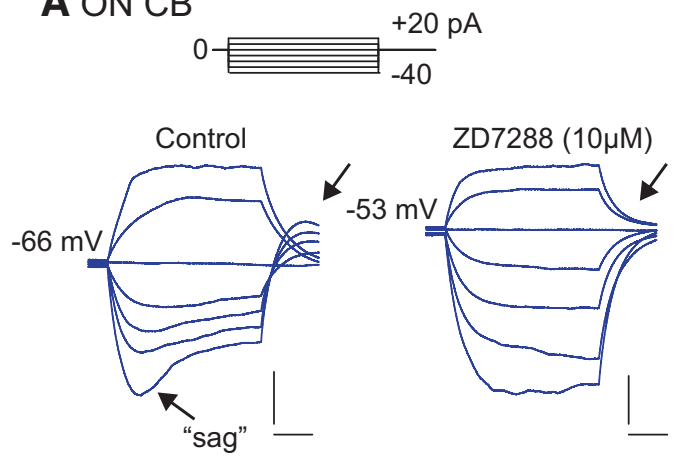

B OFF CB

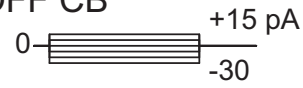

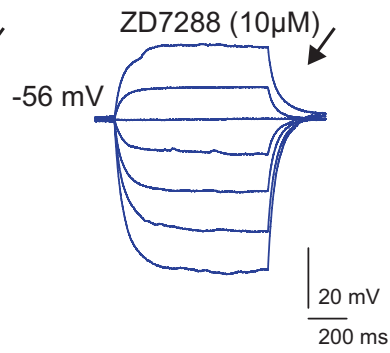

C

Control

ZD7288 $(10 \mu \mathrm{M})$

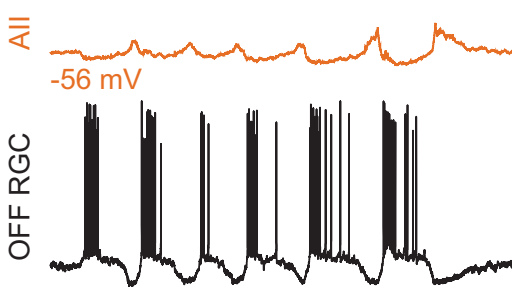

$-53 \mathrm{mV}$
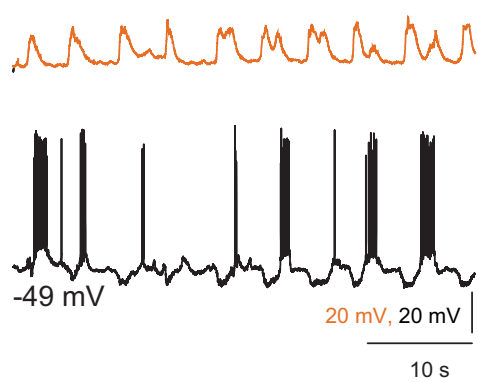

D

Inter-event Intervals - All

Inter-event Intervals - RGCs

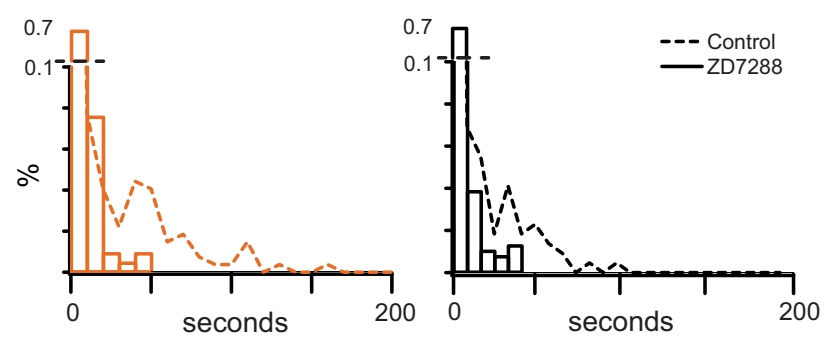

Figure 5. $I_{\mathrm{h}}$ blockade of HCN channels in CBs modulates frequency of spontaneous depolarizations. $A$, Current-clamp recording from ON CB in response to injected current in the absence and presence of $I_{\mathrm{h}}$ antagonist ZD7288. Arrows, hyperpolarizing sag and rebound depolarization indicative of $I_{\mathrm{h}}$. $\boldsymbol{B}$, Current-clamp recordings from an $0 \mathrm{FF}$ CB in response to injected current in the absence and presence of ZD7288. C, Concurrent current-clamp recordings of spontaneous depolarizations in an All and OFF RGC in whole-mount retina in the absence and presence of ZD7288. Note that the All and the $0 \mathrm{FF} \mathrm{GC} \mathrm{remain} \mathrm{anti-correlated} \mathrm{but} \mathrm{that} \mathrm{the} \mathrm{hyperpolarization} \mathrm{of} \mathrm{the} \mathrm{All} \mathrm{in} \mathrm{the} \mathrm{interwave} \mathrm{interval} \mathrm{is} \mathrm{abolished} \mathrm{by} \mathrm{ZD7288.} \mathrm{Control} \mathrm{recording} \mathrm{same} \mathrm{as} \mathrm{Figure} \mathrm{2.} \mathrm{D,} \mathrm{Summary} \mathrm{data} \mathrm{of} \mathrm{effects}$ on interwave interval distributions. Dotted lines are control distributions from Figure 2.

ized during retinal waves (Figs. 1, 4, 6, 7) indicating that there are potentially several other elements in the network generating Stage 3 waves.

\section{AII-CB interactions govern glutamatergic wave generation and propagation}

Our observations support the following model: bipolar cells oscillate intrinsically (Protti et al., 2000; Ma et al., 2005; Toychiev et al., 2013), periodically depolarizing AIIs. Since AII depolarization persists in the $\mathrm{Cx} 36 \mathrm{ko}$ (Fig. 7), this depolarization is likely to be mediated by glutamate spillover originating from ON CB terminals. By virtue of their glycinergic output (which, in the mature retina, is to some types of OFF CBs and to some types of OFF RGC, primarily $\alpha$-type cells; Demb and Singer, 2012), AIIs inhibit OFF cells and anti-correlate activity in the developing ON and OFF pathways (Akrouh and Kerschensteiner, 2013). Thus, oscillations in ON and OFF CBs are normally anti-correlated by synaptic inhibition: on depolarization it produces OFF inhibition, which acts to hyperpolarize OFF CBs and activate $I_{\mathrm{h}}$; when ON CBs hyperpolarize, OFF inhibition is relieved and $I_{\mathrm{h}}$ serves to depolarize OFF CBs. This model is consistent with the findings that OFF CBs hyperpolarize as a result of glycinergic inhibition when ON RGCs receive excitatory input during a glutamatergic wave and that synaptic inhibition generates the temporal structure of RGC firing patterns during waves (Kerschensteiner and Wong, 2008; Akrouh and Kerschensteiner, 2013).

What remains to be determined is the source of the large-scale coupling that inhibits activity in between waves. Our first hypothesis was that by virtue of their electrical coupling to each other and to ON CBs, AIIs would function to coordinate activity among neighboring $\mathrm{ON}$ CBs and propagate activity within the inner retina. The observation that AIIs continued to depolarize in a correlated fashion during waves in the Cx36 ko mouse (Fig. 7), 
A
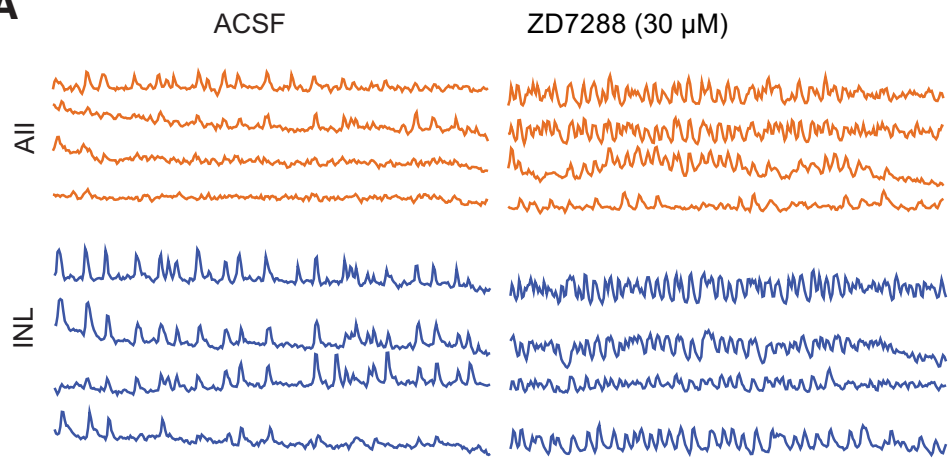

B

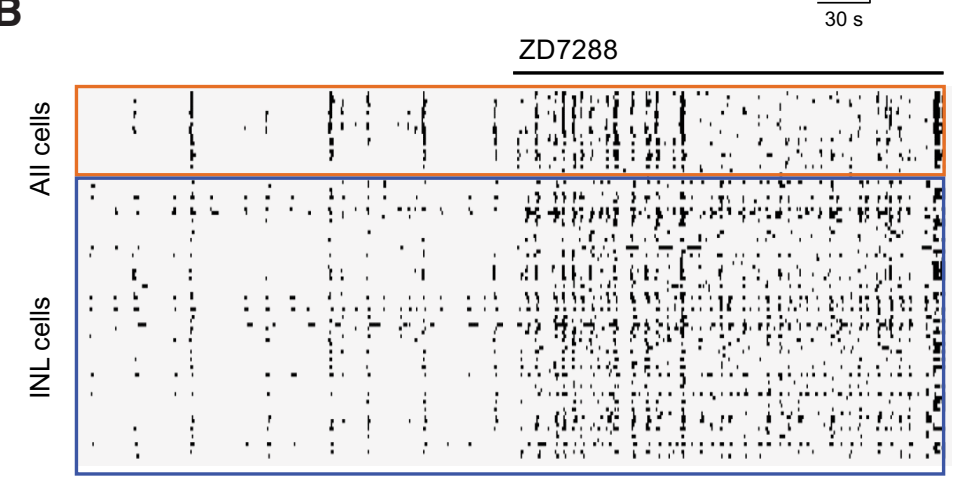

C

Proportion of cells that participate in waves
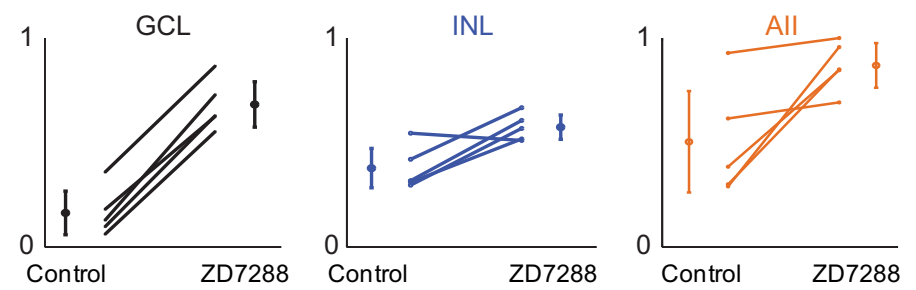

D

Proportion of cells that have no spontaneous calcium transients
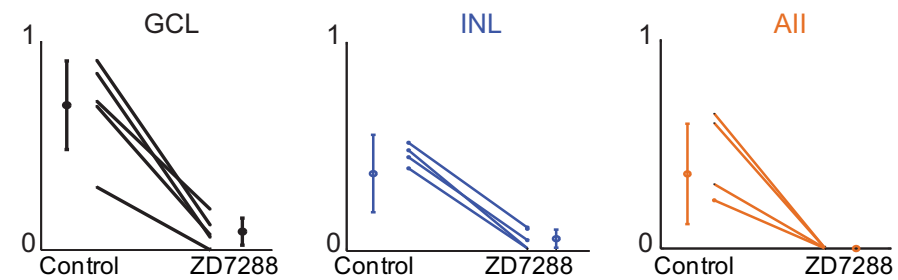

E

Inter-wave intervals
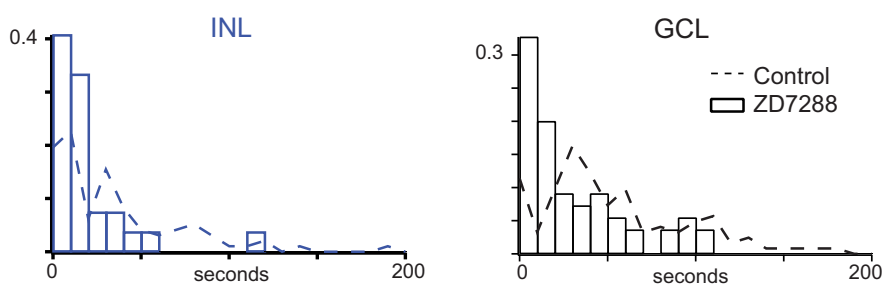

Figure 6. Blockade of HCN channels with ZD7288 abolishes wave structure. $A$, Sample $\Delta F / F$ traces from representative cells, in control ACSF (left) and after ZD7288 (right), and in Alls (top) and other unidentified INL neurons (bottom). B, Raster plots of neuronal calcium transients of $>15 \% \Delta F / F$ for all INL cells in the field of view, in control ACSF (left) and $50 \mu \mathrm{m} Z \mathrm{DD} 288$ (right). The total imaging duration was $10 \mathrm{~min}$. C, Summary of effects of ZD7288 on the average proportion of cells that participated per wave. Lines connect values of average cell participation per wave for one retina in control versus ZD7288 among GCL (left), INL neurons that are not Alls amacrine cells (center), and INL neurons that are All amacrine cells (right). Open circles are group means and SD. however, indicated that gap junction coupling was not the primary source of depolarization during glutamatergic waves; rather, depolarization appeared to be propagated primarily by glutamate spillover (Blankenship et al., 2009; Firl et al., 2013). Gap junctions, then, may serve to correlate activity of AIIs and $\mathrm{ONCBs}$ on a shorter timescale that can be assessed by calcium imaging.

It is important to note that previous studies have shown that glutamatergic waves are blocked completely by meclofenamic acid (MFA), a gap junction antagonist (Akrouh and Kerschensteiner, 2013). In contrast, RGCs from retinas of Cx36 ko, Cx45 ko, and Cx36/45 dko mice exhibit increased uncorrelated firing between waves as well as increase temporally correlated firing between spatially distant neurons during waves (Hansen et al., 2005; Torborg et al., 2005; Blankenship et al., 2011). The discrepancy between these two findings - waves with altered spontaneous spiking in Cx36/45 dko mice versus a complete blockade of activity by a gap junction antagonist-could have multiple causes: nonspecific effects of MFA, developmental compensation in the Cx36/45 dko, or involvement of connexins other than Cx36 and Cx45 in glutamatergic waves. The relative strength of these arguments has been discussed previously (Blankenship et al., 2011).

We propose that decreased neural activity during the interwave interval arises from synaptic inhibition. Based on the dramatic effect that blocking $I_{\mathrm{h}}$ has on the spatial correlations of neural activity during waves, we hypothesize that blocking $I_{\mathrm{h}}$ decouples the intrinsic activity of CBs from synaptic inhibition. In normal retinas, glutamate released during a wave excites inhibitory interneurons, which in turn synchronously hyperpolarizes $\mathrm{CB}$ terminals. As this inhibition is relieved, $I_{\mathrm{h}}$ causes $\mathrm{CBs}$ to depolarize, initiating the next wave. We propose that gap junctions containing $\mathrm{Cx} 36$ and $\mathrm{Cx} 45$ coordinate this inhibition and, therefore, coordinated inhibition underlies the silences between waves. This idea is con-

\section{$\leftarrow$}

D, Summary of effects of ZD7288 on the number of cells that never displayed calcium transients of $>15 \% \Delta F / F$. Lines connect values of number of inactive cells per retina in control versus ZD7288 among GCL (left), INL neurons that are not Alls amacrine cells (center), and INL neurons that are All amacrine cells (right). Open circles are group means and SD. E, Histogram of interwave intervals as assayed by calcium imaging for control ACSF (black) and ZD7288 (red). Inset is normalized cumulative distribution for both conditions (control: $N=150$ wave intervals and ZD7288: $N=62$ wave intervals). 
A

Cx36 INL CX36/45 INL

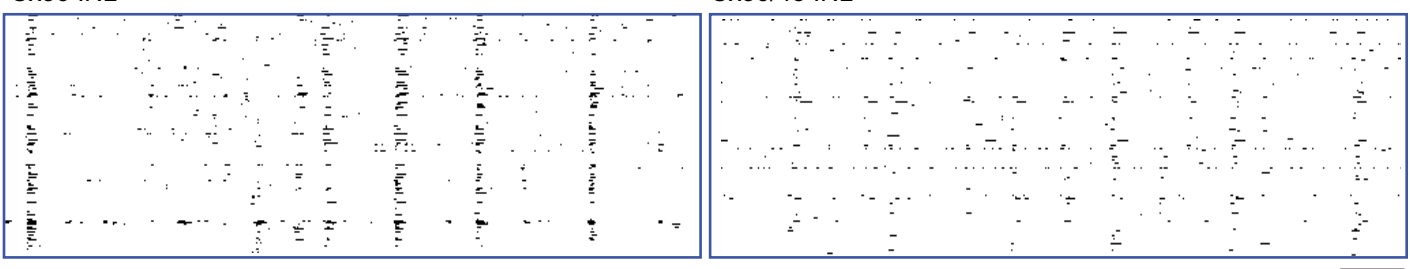

B

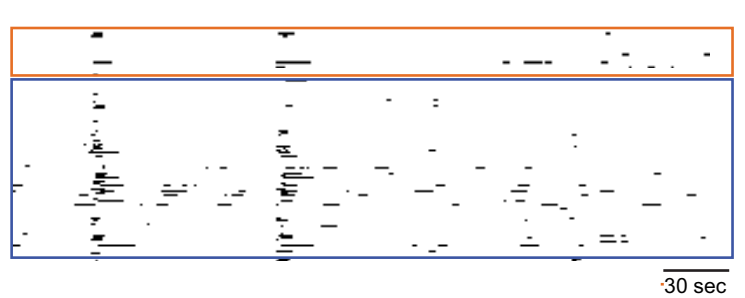

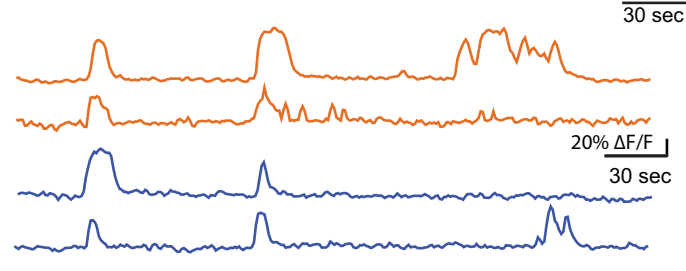

C

Proportion of cells participating in waves

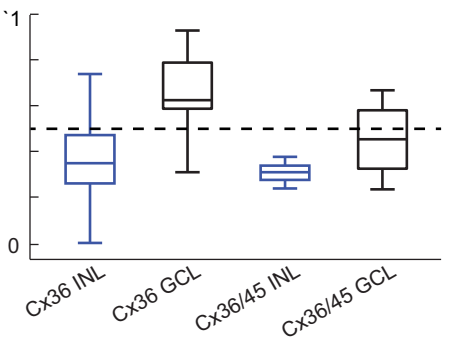

D

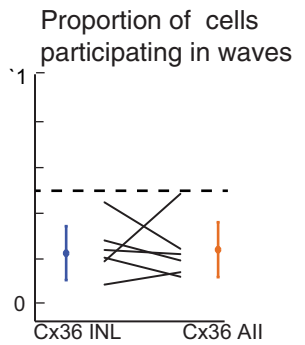

Proportion of cells that have no spontaneous calcium transients

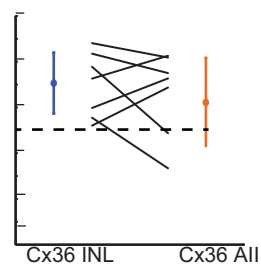

Figure 7. Connexin ko does not reduce Alls' participation in waves. A, Raster plots of neuronal calcium transients of $>15 \% \Delta F / F$ for all cells in the field of view for Cx36 ko (left) and $C \times 36 / 45 \mathrm{dko}$ (right). The total imaging duration was $5 \mathrm{~min}$. B, Raster plots of neuronal calcium transients of $>15 \% \Delta F / F$ for all Alls in the field of view (top), and other unidentified INL neurons (bottom). Recordings were performed in Cx36 ko/Fbx032-eGFP mice in which Alls express eGFP but lack Cx36. The total imaging duration was 10 min. C, Boxplot comparisons of proportion of cells that displayed transients of $>15 \% \Delta F / F$ during at least one wave. $(x 36 \mathrm{GCL}$ was found to be significantly different (Kruskal-Wallis test, $p=0.03$ ). $\boldsymbol{D}$, Proportion of cells that displayed calcium transients $>15 \% \Delta F / F$ during waves (left), versus proportion of cells that never displayed calcium transients of $>15 \% \Delta F / F$ (right). Lines connect values of proportion of Alls and other INL neurons per retina.

sistent with our observation that uncorrelated activity in the interwave interval is increased in the absence of gap junction coupling.

\section{How do glutamatergic waves compare with "wave-like" phenomena in the developed retina?}

It is instructive to compare glutamatergic waves with examples of wave-like activities observed in the mature retina. In the normal, developed retina, blockade of synaptic inputs to bipolar cells induces calcium channel-dependent oscillations in bipolar cellmembrane potential; a potential role for $I_{\mathrm{h}}$ in this process has not been investigated (Toychiev et al., 2013). These changes to membrane potential appear to induce wave-like activity that propagates across the inner retina via a combination of electrical transmission and glutamate spillover that drives spiking in ganglion cells via glutamatergic $\mathrm{CB} \rightarrow \mathrm{RGC}$ synapses (Toychiev et al., 2013). These mechanisms of propagation are similar to those that appear to underlie glutamatergic waves (Blankenship et al., 2009, 2011; Firl et al., 2013). Thus, it would seem that the neural substrate of the retina is designed to propagate activity induced by a variety of cellular processes; indeed, it was found that in the absence of synaptic transmission, pharmacological activation of calcium channels could induce propagating waves of neural activity in the developing retina (Singer et al., 2001; Torborg et al., 2004).

In the degenerating retina of the $r d 1$ mouse, a model for human retinitis pigmentosa, oscillatory spontaneous activity is observed in RGCs (Margolis et al., 2008, 2014; Stasheff, 2008;
Menzler and Zeck, 2011; Yee et al., 2012;Menzler et al., 2014). Though the spatiotemporal patterns of activity in the $r d$ mouse differs from that of retinal waves (Menzler and Zeck, 2011; Maccione et al., 2014), the activity does share many circuit features. This activity originates in the inner retina and is propagated to RGCs via $\mathrm{CB} \rightarrow \mathrm{GC}$ synapses (Borowska et al., 2011; Trenholm et al., 2012; Choi et al., 2014; Margolis et al., 2014). Activity in neurons in the INL does not appear to result solely from calcium channel-mediated bursting (Borowska et al., 2011). As it is blocked by antagonists of gap junctions, it has been suggested that this activity is an emergent property of a degenerated network (Trenholm et al., 2012; Yee et al., 2012) and can be induced in healthy retinas in response to photoreceptor bleaching (Menzler et al., 2014). More recently, however, an alternate hypothesis has emerged: oscillations in the $r d 1$ retina emerge from intrinsic bursting in AIIs; gap junctions are relevant only insofar as they permit ON CBs, hyperpolarized because of the lack of depolarizing photoreceptor input, to hyperpolarize the AII membrane potential to a level that permits bursting (Cembrowski et al., 2012; Choi et al., 2014; Margolis et al., 2014). The idea that electrical coupling allows ON CBs and AIIs to influence each other's behaviors is reinforced by a recent study of light-evoked signaling through the AII network (Grimes et al., 2014).

Together, observations from developed normal and $r d 1$ retinas indicate that activity arising in the inner retina as a result of a variety of cellular processes can become oscillatory. This oscillatory activity can be propagated through the retina by a number of 
mechanisms, and the AII, by virtue of its position in both gap junction-coupled and inhibitory circuits, can play a significant role in this propagation.

\section{References}

Ackman JB, Crair MC (2014) Role of emergent neural activity in visual map development. Curr Opin Neurobiol 24:166-175. CrossRef Medline

Akrouh A, Kerschensteiner D (2013) Intersecting circuits generate precisely patterned retinal waves. Neuron 79:322-334. CrossRef Medline

Bansal A, Singer JH, Hwang BJ, Xu W, Beaudet A, Feller MB (2000) Mice lacking specific nicotinic acetylcholine receptor subunits exhibit dramatically altered spontaneous activity patterns and reveal a limited role for retinal waves in forming $\mathrm{ON}$ and OFF circuits in the inner retina. J Neurosci 20:7672-7681. Medline

Blankenship AG, Ford KJ, Johnson J, Seal RP, Edwards RH, Copenhagen DR, Feller MB (2009) Synaptic and extrasynaptic factors governing glutamatergic retinal waves. Neuron 62:230-241. CrossRef Medline

Blankenship AG, Hamby AM, Firl A, Vyas S, Maxeiner S, Willecke K, Feller MB (2011) The role of neuronal connexins 36 and 45 in shaping spontaneous firing patterns in the developing retina. J Neurosci 31:999810008. CrossRef Medline

Boos R, Schneider H, Wässle H (1993) Voltage- and transmitter-gated currents of AII-amacrine cells in a slice preparation of the rat retina. J Neurosci 13:2874-2888. Medline

Borowska J, Trenholm S, Awatramani GB (2011) An intrinsic neural oscillator in the degenerating mouse retina. J Neurosci 31:5000-5012. CrossRef Medline

Briggman KL, Euler T (2011) Bulk electroporation and population calcium imaging in the adult mammalian retina. J Neurophysiol 105:2601-2609. CrossRef Medline

Cangiano L, Gargini C, Della Santina L, Demontis GC, Cervetto L (2007) High-pass filtering of input signals by the Ih current in a non-spiking neuron, the retinal rod bipolar cell. PLoS One 2:e1327. CrossRef Medline

Cembrowski MS, Logan SM, Tian M, Jia L, Li W, Kath WL, Riecke H, Singer JH (2012) The mechanisms of repetitive spike generation in an axonless retinal interneuron. Cell Rep 1:155-166. CrossRef Medline

Choi H, Zhang L, Cembrowski MS, Sabottke CF, Markowitz AL, Butts DA, Kath WL, Singer JH, Riecke H (2014) Intrinsic bursting of AII amacrine cells underlies oscillations in the rd1 mouse retina. J Neurophysiol 112: 1491-1504. CrossRef Medline

Deans MR, Volgyi B, Goodenough DA, Bloomfield SA, Paul DL (2002) Connexin36 is essential for transmission of rod-mediated visual signals in the mammalian retina. Neuron 36:703-712. CrossRef Medline

Demb JB, Singer JH (2012) Intrinsic properties and functional circuitry of the AII amacrine cell. Vis Neurosci 29:51-60. CrossRef Medline

Famiglietti EV Jr, Kolb H (1975) A bistratified amacrine cell and synaptic circuitry in the inner plexiform layer of the retina. Brain Res 84:293-300. CrossRef Medline

Feigenspan A, Teubner B, Willecke K, Weiler R (2001) Expression of neuronal connexin36 in AII amacrine cells of the mammalian retina. J Neurosci 21:230-239. Medline

Feigenspan A, Janssen-Bienhold U, Hormuzdi S, Monyer H, Degen J, Söhl G, Willecke K, Ammermüller J, Weiler R (2004) Expression of connexin36 in cone pedicles and OFF-cone bipolar cells of the mouse retina. J Neurosci 24:3325-3334. CrossRef Medline

Firl A, Sack GS, Newman ZL, Tani H, Feller MB (2013) Extrasynaptic glutamate and inhibitory neurotransmission modulate ganglion cell participation during glutamatergic retinal waves. J Neurophysiol 109:1969-1978. CrossRef Medline

Ford KJ, Félix AL, Feller MB (2012) Cellular mechanisms underlying spatiotemporal features of cholinergic retinal waves. J Neurosci 32:850-863. CrossRef Medline

Fuerst PG, Bruce F, Tian M, Wei W, Elstrott J, Feller MB, Erskine L, Singer JH, Burgess RW (2009) DSCAM and DSCAML1 function in self-avoidance in multiple cell types in the developing mouse retina. Neuron 64:484497. CrossRef Medline

Gong S, Zheng C, Doughty ML, Losos K, Didkovsky N, Schambra UB, Nowak NJ, Joyner A, Leblanc G, Hatten ME, Heintz N (2003) A gene expression atlas of the central nervous system based on bacterial artificial chromosomes. Nature 425:917-925. CrossRef Medline

Grimes WN, Schwartz GW, Rieke F (2014) The synaptic and circuit mech- anisms underlying a change in spatial encoding in the retina. Neuron 82:460-473. CrossRef Medline

Güldenagel M, Söhl G, Plum A, Traub O, Teubner B, Weiler R, Willecke K (2000) Expression patterns of connexin genes in mouse retina. J Comp Neurol 425:193-201. CrossRef Medline

Hansen KA, Torborg CL, Elstrott J, Feller MB (2005) Expression and function of the neuronal gap junction protein connexin 36 in developing mammalian retina. J Comp Neurol 493:309-320. CrossRef Medline

Huberman AD, Feller MB, Chapman B (2008) Mechanisms Underlying Development of Visual Maps and Receptive Fields. Annu Rev Neurosci 31: 479-509. CrossRef Medline

Kay JN, Chu MW, Sanes JR (2012) MEGF10 and MEGF11 mediate homotypic interactions required for mosaic spacing of retinal neurons. Nature 483:465-469. CrossRef Medline

Ke JB, Wang YV, Borghuis BG, Cembrowski MS, Riecke H, Kath WL, Demb JB, Singer JH (2014) Adaptation to background light enables contrast coding at rod bipolar cell synapses. Neuron 81:388-401. CrossRef Medline

Kerschensteiner D, Wong RO (2008) A precisely timed asynchronous pattern of on and off retinal ganglion cell activity during propagation of retinal waves. Neuron 58:851-858. CrossRef Medline

Kirkby LA, Sack GS, Firl A, Feller MB (2013) A role for correlated spontaneous activity in the assembly of neural circuits. Neuron 80:1129-1144. CrossRef Medline

Kolb H, Nelson R (1983) Rod pathways in the retina of the cat. Vision Res 23:301-312. CrossRef Medline

Lee EJ, Kim HJ, Kim IB, Park JH, Oh SJ, Rickman DW, Chun MH (2003) Morphological analysis of disabled-1-immunoreactive amacrine cells in the guinea pig retina. J Comp Neurol 466:240-250. CrossRef Medline

Lee EJ, Kim HJ, Lim EJ, Kim IB, Kang WS, Oh SJ, Rickman DW, Chung JW, Chun MH (2004) AII amacrine cells in the mammalian retina show disabled-1 immunoreactivity. J Comp Neurol 470:372-381. CrossRef Medline

Lin B, Jakobs TC, Masland RH (2005) Different functional types of bipolar cells use different gap-junctional proteins. J Neurosci 25:6696-6701. CrossRef Medline

Lüthi A, McCormick DA (1998) H-current: properties of a neuronal and network pacemaker. Neuron 21:9-12. CrossRef Medline

Ma YP, Pan ZH (2003) Spontaneous regenerative activity in mammalian retinal bipolar cells: roles of multiple subtypes of voltage-dependent Ca2 + channels. Vis Neurosci 20:131-139. CrossRef Medline

Ma YP, Cui J, Pan ZH (2005) Heterogeneous expression of voltagedependent $\mathrm{Na}+$ and $\mathrm{K}+$ channels in mammalian retinal bipolar cells. Vis Neurosci 22:119-133. CrossRef Medline

Maccione A, Hennig MH, Gandolfo M, Muthmann O, van Coppenhagen J, Eglen SJ, Berdondini L, Sernagor E (2014) Following the ontogeny of retinal waves: pan-retinal recordings of population dynamics in the neonatal mouse. J Physiol 592:1545-1563. CrossRef Medline

Manookin MB, Beaudoin DL, Ernst ZR, Flagel LJ, Demb JB (2008) Disinhibition combines with excitation to extend the operating range of the OFF visual pathway in daylight. J Neurosci 28:4136-4150. CrossRef Medline

Margolis DJ, Detwiler PB (2007) Different mechanisms generate maintained activity in ON and OFF retinal ganglion cells. J Neurosci 27:59946005. CrossRef Medline

Margolis DJ, Newkirk G, Euler T, Detwiler PB (2008) Functional stability of retinal ganglion cells after degeneration-induced changes in synaptic input. J Neurosci 28:6526-6536. CrossRef Medline

Margolis DJ, Gartland AJ, Singer JH, Detwiler PB (2014) Network oscillations drive correlated spiking of on and off ganglion cells in the rd1 mouse model of retinal degeneration. PLoS One 9:e86253. CrossRef Medline

Maxeiner S, Dedek K, Janssen-Bienhold U, Ammermüller J, Brune H, Kirsch T, Pieper M, Degen J, Krüger O, Willecke K, Weiler R (2005) Deletion of connexin 45 in mouse retinal neurons disrupts the rod/cone signaling pathway between AII amacrine and on cone bipolar cells and leads to impaired visual transmission. J Neurosci 25:566-576. CrossRef Medline

Menzler J, Zeck G (2011) Network oscillations in rod-degenerated mouse retinas. J Neurosci 31:2280-2291. CrossRef Medline

Menzler J, Channappa L, Zeck G (2014) Rhythmic ganglion cell activity in bleached and blind adult mouse retinas. PLoS One 9:e106047. CrossRef Medline

Münch TA, da Silveira RA, Siegert S, Viney TJ, Awatramani GB, Roska B 
(2009) Approach sensitivity in the retina processed by a multifunctional neural circuit. Nat Neurosci 12:1308-1316. CrossRef Medline

Murphy GJ, Rieke F (2008) Signals and noise in an inhibitory interneuron diverge to control activity in nearby retinal ganglion cells. Nat Neurosci 11:318-326. CrossRef Medline

Protti DA, Flores-Herr N, von GersdorffH (2000) Light evokes Ca2 + spikes in the axon terminal of a retinal bipolar cell. Neuron 25:215-227. CrossRef Medline

Rice DS, Curran T (2000) Disabled-1 is expressed in type AII amacrine cells in the mouse retina. J Comp Neurol 424:327-338. CrossRef Medline

Sernagor E, Young C, Eglen SJ (2003) Developmental modulation of retinal wave dynamics: shedding light on the GABA saga. J Neurosci 23:76217629. Medline

Siegert S, Scherf BG, Del Punta K, Didkovsky N, Heintz N, Roska B (2009) Genetic address book for retinal cell types. Nat Neurosci 12:1197-1204. CrossRef Medline

Singer JH, Mirotznik RR, Feller MB (2001) Potentiation of L-type calcium channels reveals nonsynaptic mechanisms that correlate spontaneous activity in the developing mammalian retina. J Neurosci 21:8514-8522. Medline

Stasheff SF (2008) Emergence of sustained spontaneous hyperactivity and temporary preservation of OFF responses in ganglion cells of the retinal degeneration (rd1) mouse. J Neurophysiol 99:1408-1421. CrossRef Medline

Stosiek C, Garaschuk O, Holthoff K, Konnerth A (2003) In vivo two-photon calcium imaging of neuronal networks. Proc Natl Acad Sci U S A 100: 7319-7724. CrossRef Medline

Strettoi E, Raviola E, Dacheux RF (1992) Synaptic connections of the narrow-field, bistratified rod amacrine cell (AII) in the rabbit retina. J Comp Neurol 325:152-168. CrossRef Medline

Tian M, Jarsky T, Murphy GJ, Rieke F, Singer JH (2010) Voltage-gated Na channels in AII amacrine cells accelerate scotopic light responses mediated by the rod bipolar cell pathway. J Neurosci 30:4650-4659. CrossRef Medline
Torborg C, Wang CT, Muir-Robinson G, Feller MB (2004) L-type calcium channel agonist induces correlated depolarizations in mice lacking the beta2 subunit nAChRs. Vision Res 44:3347-3355. CrossRef Medline

Torborg CL, Hansen KA, Feller MB (2005) High frequency, synchronized bursting drives eye-specific segregation of retinogeniculate projections. Nat Neurosci 8:72-78. CrossRef Medline

Toychiev AH, Yee CW, Sagdullaev BT (2013) Correlated spontaneous activity persists in adult retina and is suppressed by inhibitory inputs. PLoS One 8:e77658. CrossRef Medline

Trenholm S, Borowska J, Zhang J, Hoggarth A, Johnson K, Barnes S, Lewis TJ, Awatramani GB (2012) Intrinsic oscillatory activity arising within the electrically coupled AII amacrine-ON cone bipolar cell network is driven by voltage-gated $\mathrm{Na}+$ channels. J Physiol 590:2501-2517. CrossRef Medline

van Wyk M, Wässle H, Taylor WR (2009) Receptive field properties of ONand OFF-ganglion cells in the mouse retina. Vis Neurosci 26:297-308. CrossRef Medline

Völgyi B, Pan F, Paul DL, Wang JT, Huberman AD, Bloomfield SA (2013) Gap junctions are essential for generating the correlated spike activity of neighboring retinal ganglion cells. PLoS One 8:e69426. CrossRef Medline

Wong WT, Wong RO (2001) Changing specificity of neurotransmitter regulation of rapid dendritic remodeling during synaptogenesis. Nat Neurosci 4:351-352. CrossRef Medline

Yee CW, Toychiev AH, Sagdullaev BT (2012) Network deficiency exacerbates impairment in a mouse model of retinal degeneration. Front Syst Neurosci 6:8. CrossRef Medline

Zheng J, Lee S, Zhou ZJ (2006) A transient network of intrinsically bursting starburst cells underlies the generation of retinal waves. Nat Neurosci 9:363-371. CrossRef Medline

Zhou ZJ, Zhao D (2000) Coordinated transitions in neurotransmitter systems for the initiation and propagation of spontaneous retinal waves. J Neurosci 20:6570-6577. Medline 